\title{
Marcin Chudoba
}

Wydział Nauk Humanistycznych

Uniwersytet Pedagogiczny im. KEN w Krakowie

e-mail: marcin.chudoba@up.krakow.pl

ORCID: 0000-0002-1005-9693

\section{Conan Edogawa - detektyw z komiksów Gōshō Aoyamy jako superbohater}

Pierwszy numer magazynu „Action Comics” wydany w Stanach Zjednoczonych w czerwcu 1938 roku, w skład którego wchodził trzynastostronicowy komiks o przygodach Supermana (alter ego dziennikarza Clarka Kenta), autorstwa Jerry'ego Siegela i Joe'go Shustera, zrewolucjonizował amerykański rynek komiksowy. Jack Liebowitz, właściciel oficyny National Allied Publications, odpowiedzialnej za publikację czasopisma, zachowując ostrożność, zlecił druk jedynie dwustu tysięcy egzemplarzy premierowego wydania „Acion Comics" $^{\prime 1}$. Nie przewidział bowiem, że opowieść o pierwszym amerykańskim superbohaterze spotka się z ogromnym zainteresowaniem czytelników. W 1939 roku National Allied Publication rozpoczęło publikację serii „Superman" oraz licencjonowanych pasków komiksowych zamieszczanych na łamach prasy. Rok później historyjki obrazkowe z Clarkiem Kentem sprzedawały się w miesięcznych nakładach miliona dwustu pięćdziesięciu tysięcy egzemplarzy ${ }^{2}$. Sukces Supermana sprawił, że na rynku masowo zaczęły pojawiać się komiksy ukazujące losy kolejnych superbohaterów. Współcześnie opowieści o potężnych herosach nadal cieszą się niesłabnącą popularnością,

1 B. W. Wright, Comic Book Nation. The Transformation of Youth Culture in America, Baltimore \& London 2003, s. 9.

2 D. Hajdu, The Ten-Cent Plague. The Great Comic-Book Scare and How It Changed America, New York 2008, s. 31. 
która rozprzestrzenia się na inne media. Tematyka komiksowa zajmuje nieustająco wysoką pozycję w planach studiów filmowych. Tomasz Żaglewski zauważa, że w samym 2016 roku premierę miało sześć adaptacji historyjek obrazkowych, przy czym każda z nich nie była samodzielną produkcją, lecz epizodem $w$ wytrwale budowanych seriach i franczyzach, obecnych na ekranach kin od wielu lat ${ }^{3}$.

Superbohaterowie obecni są $\mathrm{w}$ japońskiej kulturze popularnej od lat trzydziestych XX wieku. W 1930 lub 1931 roku Ichirō Suzuki oraz Takeo Nagamatsu, narrator i twórca grafik do tradycyjnego japońskiego ulicznego teatru obrazkowego zwanego kamishibai, przedstawili pierwszą opowieść o przygodach Złotego Nietoperza (Ōgon Batto) ${ }^{4}$. Japoński superbohater pochodził z mitycznej Atlantydy, nosił hiszpański hubon z kryzą i białymi pończochami, czerwoną pelerynę oraz rapier, a głowę zastępowała mu złota czaszka $^{5}$. Niezwykłą kreację postaci orientalnego herosa, wykorzystującą elementy wywodzące się z kultury europejskiej, można tłumaczyć japońską otwartością na wpływy z zewnątrz oraz dążeniem do jednoczesnego zasymilowania i przetworzenia ich celem stworzenia czegoś własnego, unikalnego ${ }^{6}$.

Współczesna forma komiksu japońskiego, znana na Zachodzie jako manga, ukształtowała się po zakończeniu II wojny światowej. Przyczyniły się do tego amerykańskie wpływy kulturowe, czynniki ekonomiczne, niepozwalające m.in. na druk w kolorze oraz talent i ciężka praca autorów ${ }^{7}$. Japońskie komiksy poruszają różnorodne tematy, wykorzystywane są jako nośniki codziennej informacji, pomagają $\mathrm{w}$ rozwiązywania problemów, wspierają działania edukacyjne, lecz przede wszystkim służą rozrywce i spełnianiu pragnień ${ }^{8}$.

Celem niniejszej pracy jest analiza postaci detektywa-amatora, Conana Edogawy, protagonisty mangi Meitantei Conan (1994-obecnie) autorstwa Gōshō Aoyamy jako wariacji na temat superbohatera. Materiał badawczy,

3 T. Żaglewski, Kinowe uniwersum superbohaterów. Analiza wspótczesnego filmu komiksowego, Warszawa 2017, s. 16.

4 R. Kołsut, Pradziadkowie Supermana - genealogia komiksowych superbohaterów, w: Heroica. Bohaterstwo w literaturze i kulturze europejskiej, red. A. Gawarecka, W. Szturc, E. Wesołowska, Poznań 2019, s. 305.

5 Tamże, s. 305-306.

6 Uwagę na takie działania twórców kultury japońskiej zwraca Natalia Dmitruk, powołując się na wcześniejsze ustalenia Beaty Kubiak Ho-Chi. Zob. N. Dmitruk, Wierzenia z perspektywy japońskiej. Mushishi Yuki Urushibary, „Literatura i Kultura Popularna” 2017, nr 23, s. 93.

7 J. E. Ingulsrud, K. Allen, Reading Japan Cool. Patterns of Manga Literacy and Discourse, Lanham 2009, s. 60 .

8 A. Materne, Fenomen mangi i anime w środowisku młodzieży. Studium dyfuzji kultur, Kraków 2019, s. 123. 
oprócz komiksowego cyklu, stanowią również serial animowany będący jego adaptacją oraz powiązane z nim filmy kinowe ${ }^{9}$.

\section{Gōshō Aoyama i jego twórczość}

Gōshō Aoyama interesuje się komiksami od najmłodszych lat. W trakcie studiów w Akademii Sztuk Pięknych Uniwersytetu Nihon należał do klubu mangi ${ }^{10}$. Tam poznał Abego Yutakę, u którego pracował jako asystent. Doświadczenie zebrane $\mathrm{w}$ tym czasie sprawiło, że pierwszy komiks Aoyamy zatytułowany Sarigenaku Lupin otrzymał wyróżnienie czasopisma "Shūkan Shōnen Magazine". Niestety, manga nie spotkała się z ciepłym przyjęciem redaktora naczelnego, który uznał, że styl rysowania Aoyamy nie pasuje do tego magazynu ${ }^{11}$. Niezrażony niepowodzeniem autor udał się do redakcji "Shūkan Shōnen Sunday", dla której stworzył romantyczną komedię science-fiction, zatytułowaną Chotto Mattete ${ }^{12}$. W 1986 roku otrzymał za nią nagrodę $\mathrm{w}$ konkursie dla najlepszych debiutantów w kategorii komiks dla chłopców ${ }^{13}$. Aoyama na stałe związał się "Shūkan Shōnen Sunday". Na łamach czasopisma rozpoczęła się publikacja komediowo-kryminalnego cyklu Magic Kaito o przygodach młodocianego złodzieja-iluzjonisty Kaitō Kida (alter ego licealisty Kaito Kuroby) ${ }^{14}$. Dwanaście miesięcy później

9 Ponieważ manga Meitantei Conan nigdy nie została wydana w Polsce, jako materiał źródłowy posłużyła japońska wersja komiksu. W przypadku odniesień do serialowej adaptacji mangi oraz pierwszego filmu kinowego, emitowanych przez polskie oddziały AXN Sci-fi oraz AXN Spin, zdecydowano się na używanie polskich tytułów tychże. Opis 12. odcinka serii Detektyw Conan, http://www.tv.pl/opis/s_6_p_9452_Detektyw_Conan.xhtml [dostęp: 08.03.2020]; Chudi X, Lupin, Blade i Detektyw Conan na antenie AXN Spin, https://anime.com.pl/Lupin \%2C_Blade_i_Detektyw_Conan_na_antenie_AXN_Spin,news,read,6303.html [dostęp 08.03.2020].

10 J. Więckowski, Detective Conan - na tropie swojego ciała. Świat pod lupa, „Magazyn Arigato. Azjatycki Komiks i Animacja" 2012, nr 14, s. 38.

11 Tamże, s. 38.

12 Manga tworzona jest dla odbiorców w każdym wieku. Kierując się kryterium demograficznym można podzielić ją na sześć kategorii: kodomo (dla dzieci), shōjo (dla dziewczynek, nastolatek), shōnen (dla chłopców, nastolatków), josei (dla młodych kobiet), seinen (dla młodych mężczyzn) oraz gekiga (dla dojrzałych, dorosłych czytelników). Oprócz tego stosuje się podziały ze względu na tematykę, charakterystyczne dla literatury i filmów, jak np. horror, komedia czy romans. Szerzej zob. J. Zaremba-Penk, Ikonografia mangi. Wpływy tradycji rodzimej i zachodnich twórców na wybranych japońskich artystów mangowych, Bydgoszcz 2019, s. 49-53.

13 Gosho Aoyama's Profile, Oficjalna strona internetowa Gōshō Aoyama Manga Factory, https://www.gamf.jp/english/41.html [dostęp 23.02.2020].

14 Informacje na podstawie wydania kolekcjonerskiego z 2011 roku. G. Aoyama, Magic Kaito Treasured Edition t. 1, Tokio 2011. 
ukazał się pierwszy rozdział mangi Yaiba, poświęconej przygodom Yaiby Kurogane, nastoletniego chłopaka, który przemierza świat, aby zostać prawdziwym samurajem ${ }^{15}$. W 1992 roku tytuł ten zapewnił Aoyamie zwycięstwo w trzydziestym ósmym konkursie Shogakukan Manga Award w kategorii komiks dla dzieci. Prawdziwą popularność przyniosła mu dopiero manga Meitantei Conan (na Zachodzie znana również jako Case Closed bądź Detective Conan), publikowana nieustannie od roku 1994 i nagrodzona w czterdziestym szóstym konkursie Shogakukan Manga Award w kategorii komiks dla chłopców ${ }^{16}$. W 2019 roku łączna liczba sprzedanych egzemplarzy dziewięćdziesięciu czterech tomów przywołanego tytułu przekroczyła dwieście trzydzieści milionów, a na ekrany kin trafił dwudziesty pierwszy film animowany będący adaptacją cyklu ${ }^{17}$.

\section{Meitantei Conan - zarys fabuły, cechy mangi i jej adaptacji}

W zarysie fabuła cyklu prezentuje się następująco: Siedemnastoletni Shin'ichi Kudō jest genialnym detektywem-amatorem, który zasłynął tym, iż wielokrotnie wspierał tokijską policję w rozwiązywaniu śledztw. Pewnego dnia, podczas wizyty w parku rozrywki, Shin'ichi staje się świadkiem podejrzanej transakcji przeprowadzanej przez mężczyzn w czerni. Przestępcy postanawiają usunąć młodego detektywa i podają mu kapsułkę z prototypem nowej trucizny. Jednak Shin'ichi nie umiera. Okazuje się, że w wyniku działania substancji jego ciało skurczyło się. Aby uchronić siebie i swoich najbliższych przed przestępcami, za radą przyjaciela, profesora Hiroshiego Agasy, Shin'ichi przyjmuje nową tożsamość, stając się Conanem Edogawą (imię zaczerpnięte od Artura Conana Doyle'a, nazwisko od Ranpo Edogawy - japońskiego autora kryminałów) ${ }^{18}$. Następnie wprowadza się do miesz-

15 Yaiba w bazie MyAnimeList, https://myanimelist.net/manga/1631/Yaiba [dostęp 23.02.2020].

16 Gosho Aoyama's Profile... [dostęp 23.02.2020].

17 TMS Entertainment USA, A Massive Hit Series! Detective Conan: The Fist of Blue Sapphire, to be Released Nationwide in Japan on April 12th, 2019, http://www.tms-e.co.jp/english/pdf/2019 0408_conan_movie_en.pdf [dostęp 23.02.2020].

18 Można więc uznać, że Conan Edogawa, a także poświęcony mu cykl są swoistym amalgamatem łączącym tradycje brytyjskiej i japońskiej literatury kryminalnej. Ponadto wykorzystanie nazwisk pisarzy może wytworzyć w umyśle odbiory obraz, będący wiązką symultanicznie powiązanych informacji, które rozwijają się dzięki narastającym, zabarwionym emocjonalnie wspomnieniom i skojarzeniom związanym z lekturą twórczości Doyle'a i Rampo. Szerzej na temat roli umysłu w odbiorze literatury pisała Magdalena Rembowska-Płuciennik. Zob. M. Rembowska-Płuciennik, Poetyka intersubiektywności. Kognitywistyczna teoria narracji a proza XX wieku, Torun 2012, s. 255-312. 
kania koleżanki z klasy Ran Mōri oraz jej ojca, prywatnego detektywa Kogorō Mōriego. Odtąd rozpoczyna śledztwo, którego celem jest odnalezienie przestępców z parku rozrywki oraz zdobycie antidotum na eksperymentalną truciznę ${ }^{19}$.

Powyższy opis wskazuje, że Meitantei Conan wpisuje się w nurt komiksów inspirowanych szeroko pojętą literaturą kryminalną. Kierując się typologią zaproponowaną przez Ottona Penzlera, korzeni przygód Conana Edogawy należy szukać przede wszystkim w klasycznej powieści detektywistycznej (detective story) $\mathrm{z}$ detektywem-amatorem $\mathrm{w}$ roli głównej ${ }^{20}$. Wprowadzenie na karty komiksu postaci pracujących w tokijskiej policji, m.in. inspektora Jūzō Megurego, sierżanta Wataru Takakiego czy młodszej inspektor Miwako Satō, oraz poświęcenie im osobnych rozdziałów/odcinków ${ }^{21}$, sugeruje, że Aoyama czerpie też z powieści policyjnych procedur (police procedural), ukazujących działanie bohatera zbiorowego, instytucji ${ }^{22}$. Wątek walki z Czarną Organizacją 23, grupą przestępczą poszukiwaną przez FBI oraz CIA, której członkowie przyczynili się do przemiany Shin'ichiego w Conana, wpisuje się w nurt thrillerów, czyli utworów charakteryzujących się wartkim strumieniem zdarzeń ${ }^{24}$. Interesującym źródłem wiedzy na temat kryminałów, z których czerpie artysta, jest Ilustrowana encyklopedia detektywów Gōshō Aoyamy ${ }^{25}$. Jej kolejne odsłony umieszczane są na obwolucie każdego z tomów wchodzących w skład cyklu. Znajdują się tam informacje na temat jednej, wybranej literackiej bądź filmowej postaci oraz utwór z jej udziałem polecany przez Aoyamę. Encyklopedia obejmuje zarówno klasycznych detektywów,

19 Opisane wydarzenia zostały ukazane w pierwszym tomie mangi oraz w pierwszym odcinku serialu animowanego. G. Aoyama, Meitantei Conan t. 1, Tokio 1994; Detektyw Conan odc. 1, reż. K. Kodama, Japonia 1996.

${ }^{20} \mathrm{~W}$ niniejszym artykule wykorzystano analizę typologii Ottona Penzlera, przedstawioną przez Mariusza Czubaja. Zob. M. Czubaj, Etnolog w Mieście Grzechu. Powieść kryminalna jako świadectwo antropologiczne, Gdańsk 2010, s. 36-41.

21 Wątki poświęcone pracownikom policji pojawiły się m.in. w 21. tomie, a następnie zostały zekranizowane w 146. i 147. odcinku serialu. G. Aoyama, Meitantei Conan t. 21, Tokio 1998, s. 121-172; Detektyw Conan odc. 146-147, reż. K. Kodama, Y. Yamamoto, Japonia 1999.

22 M. Czubaj, Etnolog w Mieście Grzechu, s. 37.

23 Tłumaczenie własne, w oryginale 黒の組織 (Kuro no Soshiki).

${ }^{24}$ Czubaj podkreśla, że jest to brytyjskie rozumienie thrillera. Zob. M. Czubaj, Etnolog w Mieście Grzechu, s. 38. Cechy charakterystyczne dla thrillera w rozumieniu brytyjskim uwydatniają się w 425. odcinku, będącym adaptacją fragmentów 48. i 49. tomu mangi. G. Aoyama, Meitantei Conan, t. 48, Tokio 2005, s. 141-174; G. Aoyama, Meitantei Conan, t. 49, Tokio 2005, s. 5-70; Detektyw Conan, odc. 425, reż. M. Satō, Japonia 2006.

25 Tłumaczenie własne, w oryginale 青山剛昌の名探偵図鑑 (Aoyama Gōshō no Meitantei Zukan). 
by wskazać Sherlocka Holmesa, Herkulesa Poirot czy Kogorō Akechiego, jak również innych bohaterów literatury popularnej, np. Arsène'a Lupina, Hannibala Lectera, kota Koko czy Lisbeth Salander ${ }^{26}$.

Komiks o przygodach Conana Edogawy i jego adaptacje stanowią przykład narracji transmedialnej. Według Henry'ego Jenkinsa opowiadanie transmedialne:

rozwija się na różnych platformach medialnych, a każdy tekst stanowi wyróżniającą się i ważną część całości. W idealnej formie opowiadania transmedialnego każde medium porusza się $\mathrm{w}$ sferze, w której jest najlepsze, tak aby historia mogła zostać wprowadzona $\mathrm{w}$ filmie, a rozwinięta przez telewizję, powieści i komiksy. Jej świat może być eksplorowany w grze komputerowej lub doświadczany jako jedna $\mathrm{z}$ atrakcji w parku rozrywki. Każda forma dostępu do marki powinna być samowystarczalna, abyśmy nie musieli obejrzeć filmu po to, by cieszyć się grą, i odwrotnie. Każdy produkt jest punktem dostępu do marki jako całości ${ }^{27}$.

Oprócz mangi Meitantei Conan oraz anime stworzonego na jej podstawie na rynku dostępne są pełnometrażowe filmy kinowe, produkcje aktorskie $^{28}$, powieści ${ }^{29}$, a nawet historyjki obrazkowe poświęcone postaciom innym niż Conan Edogawa ${ }^{30}$. Często zdarza się, że wydarzenia ukazane w serialu nie znajdują swojego odzwierciedlenia $\mathrm{w}$ mandze. Mowa tu o tzw. anime original episodes, czyli odcinkach wyprodukowanych na potrzeby telewizji lub specjalnych wydań kolekcjonerskich ${ }^{31}$. Niemniej odcinki tego typu nie wpływają na przebieg głównego wątku fabularnego i służą jako „wypeł-

26 G. Aoyama, Meitantei Conan, t. 1, obwoluta; G. Aoyama, Meitantei Conan, t. 2, Tokio 1994, obwoluta; G. Aoyama, Meitantei Conan, t. 3, Tokio 1994, obwoluta; G. Aoyama, Meitantei Conan, t. 4, Tokio 1995, obwoluta; G. Aoyama, Meitantei Conan, t. 19, Tokio 1998, obwoluta; G. Aoyama, Meitantei Conan, t. 61, Tokio 2008, obwoluta; G. Aoyama, Meitantei Conan, t. 84, Tokio 2014, obwoluta.

${ }^{27}$ H. Jenkins, Kultura konwergencji. Zderzenie starych i nowych mediów, przeł. M. Bernatowicz, M. Filiciak, Warszawa 2007, s. 95-96.

${ }_{28}$ Oficjalna strona serialu aktorskiego Kudō Shin'ichi e no Chōsenjō, https://www.ytv.co.jp/ conan-drama/ [dostęp 08.09.2020].

29 Baza MyAnimeList podaje, że w latach 2005-2012 ukazało się dziewięć powieści o przygodach Conana. Detective Conan w bazie MyAnimeList, https://myanimelist.net/manga/11176/ Detective_Conan [dostęp 08.09.2020].

30 Mowa tu o mandze Meitantei Conan: Zero no Tea Time poświęconej postaci potrójnego agenta - Tōru Amuro, tworzonej przez Araia Takahiro. Meitantei Conan: Zero no Tea Time w bazie MyAnimeList, https://myanimelist.net/manga/114379/Meitantei_Conan_Zero_no_Tea_Time [dostęp 08.09.2020].

31 Przykładem może być tutaj odcinek walentynkowy z 1996 roku. Detektyw Conan, odc. 6, reż. K. Kodama, Japonia 1996. 
niacze" czasu antenowego w sytuacjach, gdy zabraknie materiału do ekranizacji. W przypadku filmów kinowych znajomość którejkolwiek z przywołanych uprzednio form opowieści o Conanie Edogawie również nie jest konieczna, bowiem każdy z obrazów rozpoczyna się rekapitulacją najważniejszych wydarzeń cyklu. Zdarza się również, że postać stworzona na potrzeby jednego z mediów wchodzących w skład franczyzy Meitantei Conan, zostaje zaadaptowana do pozostałych. Przykładem jest tutaj inspektor Ninzaburō Shiratori, który pojawił się po raz pierwszy w filmie Detektyw Conan: Architekt zniszczenia z 1997 roku, a na kartach mangi zadebiutował dopiero rok później ${ }^{32}$.

Nieustanny rozwój franczyzy może doprowadzić do sytuacji, w której prezentowane informacje wzajemnie się wykluczają. Według mangi oraz serialu animowanego pierwsza sprawa rozwiązana przez Shin'ichiego była związana $\mathrm{z}$ morderstwem na pokładzie samolotu ${ }^{33}$. Jednak $\mathrm{w}$ wydanym w 2008 roku odcinku specjalnym, przeznaczonym na rynek DVD, pojawia się informacja, że pierwsze śledztwo Shin'ichiego dotyczyło mężczyzny oskarżonego o zabicie swojej babci ${ }^{34}$. Innym przykładem wzajemnego wykluczania się informacji jest ostatnia scena filmu Meitantei Conan: Seikimatsu no Majutsushi ${ }^{35}$, w której Kaitō Kid pojawia się przebrany za Shin'ichiego, aby utwierdzić Ran w przekonaniu, że Conan i Shin'ichi to dwie różne osoby. Jednak w mandze Kaitō Kid poznaje prawdę na temat nastoletniego detektywa dużo później ${ }^{36}$. Przywołane przykłady można tłumaczyć zwykłym niedopatrzeniem twórców lub świadomym odcięciem się od pierwowzoru celem swobodnej realizacji wizji artystycznej reżyserów animacji.

Analiza zebranego materiału pozwala również na stwierdzenie, że Aoyama, jak i twórcy animowanej wersji przygód Conana Edogawy chętnie posługują się transfikcjonalnością. Ksenia Olkusz opisuje transfikcjonalność jako twórczą relację zachodzącą między tekstami kultury, polegającą na współdzieleniu przez nie komponentów narracyjnych, takich jak fikcyjne postaci,

32 Detektyw Conan: Architekt zniszczenia, reż. K. Kodama, Japonia 1997; G. Aoyama, Meitantei Conan, t. 21, s. 142.

33 G. Aoyama, Meitantei Conan t. 21, s. 53-120; Detektyw Conan odc. 162, reż. K. Kodama, Y. Yamamoto, Japonia 1999.

34 Meitantei Conan Magic File 2: Kudou Shin'ichi Nazo no Kabe to Kuro Lab Jiken, reż. Y. Yamamoto, Japonia 2008.

35 Meitantei Conan: Seikimatsu no Majutsushi, reż. K. Kodama, Japonia 1999.

${ }^{36}$ W 96. tomie Kaitō Kid opisuje Conana i Heijiego Hattoriego jako dwóch licealnych detektywów (高校生探偵 2 人に...), co oznacza, iż wie, że Conan to Shin'ichi. G. Aoyama, Meitantei Conan, t. 96, Tokio 2019, s. 63. 
lokalizacje, całe uniwersa czy artefakty ${ }^{37}$. Zabieg ten nie jest formą cytatu, lecz przeniesieniem elementów pierwowzoru $\mathrm{w}$ nowe środowisko narracyjne, co pozwala twórcy na odmienny rozwój zapożyczonych składników ${ }^{38}$. Po tego typu zabieg sięga Aoyama, przenosząc Kaitō Kida z kart Magic Kaito do cyklu Meitantei Conan, jednocześnie rozbudowując i modyfikując jego życiorys ${ }^{39}$. Innym przykładem łączenia elementów z różnych tekstów kultury jest film pełnometrażowy Meitantei Conan: Baker Street no Bōrei ${ }^{40}$. Tytułowy bohater wraz z przyjaciółmi zostaje uwięziony $\mathrm{w}$ wirtualnym Londynie z czasów Sherlocka Holmesa. Akcja filmu koncentruje się wokół zagadki Kuby Rozpruwacza. Wraz z rozwojem fabuły protagoniści spotykają postaci z powieści autorstwa Artura Conana Doyle'a, takie jak Sebastian Moran czy profesor Moriarty. W tym przypadku możemy mówić o rozszerzeniu uprzedniej fikcji (proza Doyle'a) przez transfikcję (film kinowy), polegającym na stworzeniu narracji o tym, co działo się w konkretnym momencie tekstu inicjalnego ${ }^{41}$. Wynika to $\mathrm{z}$ faktu, że w czasie gdy Edogawa i jego przyjaciele trafiają do Londynu, Sherlock oraz Watson przebywają w Dartmoor, gdzie starają rozwiązać się zagadkę psa Baskerville’ów.

\section{Holmes ery Heisei}

Bogdan Trocha zwraca uwagę, że bohaterowie literatury popularnej mają swoje pierwowzory w mitach, legendach, eposach heroicznych czy w Starym i Nowym Testamencie ${ }^{42}$. Superman nosi więc cechy Chrystusa - obaj byli jedynymi synami mądrych, potężnych ojców "żyjących w niebiosach", a po pojawieniu się na Ziemi czynili cuda i wspierali ludzkość ${ }^{43}$. Billy Batson, który pojawił się w 1940 roku na łamach magazynu „Whiz Comics” wyda-

37 K. Olkusz, Transfikcjonalność w literaturze, „Zagadnienia Rodzajów Literackich” 2018, nr 61, z. 1, s. 159 .

38 Tamże.

39 Kaitō Kid pojawił się po raz pierwszy na łamach Meitantei Conan w 16. tomie cyklu. G. Aoyama, Meitantei Conan, t. 16, Tokio 1997, s. 112.

40 Meitantei Conan: Baker Street no Bōrei, reż. K. Kodama, Japonia 2002.

41 Więcej na ten temat zob. P. Marciniak, Transfikcjonalność, „Forum Poetyki” 2015, nr 2, s. 105.

42 B. Trocha, Typologia herosa w literaturze popularnej, w: Heroica. Bohaterstwo w literaturze $i$ kulturze europejskiej, s. 279-286.

43 D. Hajdu, The Ten-Cent Plague, s. 29. Na podobieństwa Supermana do Chrystusa zwraca też uwagę Przemysław Zawrotny, który powołując się na Rogera Sabina (brytyjskiego autora komiksów i nauczyciela akademickiego), opisuje opowieść o śmierci i zmartwychwstaniu Clarka Kenta jako analogiczną do ostatnich dni Jezusa. Zob. P. Zawrotny, Zamiana herosa w superherosa, „Zeszyty Komiksowe” 2018, nr 26, s. 8. 
wanego przez Fawcett Publications, po wypowiedzeniu magicznego słowa „Shazam!" (litery tworzące wyraz pochodzą od Salomona, Herkulesa, Atlasa, Zeusa, Achillesa i Merkurego) stawał się Kapitanem Marvelem, a debiutująca rok później Wonder Woman była Amazonką ${ }^{44}$.

Należy jednak zwrócić uwagę na fakt, że jedynie niektórzy superbohaterowie mają mitologiczne korzenie. Ponadto część $\mathrm{z}$ nich $\mathrm{w}$ ogóle nie posiada nadzwyczajnych mocy. Czy zasadnym jest traktowanie ich na równi z Supermanem lub Wonder Woman? Roz Kaveney opisuje superbohatera jako postać obdarzoną mocami, broniącą słabszych, walczącą o prawdę i sprawiedliwość. Przy takim założeniu superbohaterem można nazwać również protagonistę, który nie ma żadnych niezwykłych zdolności, choć herosi tego typu stanowią mniejszość ${ }^{45}$. Warto zwrócić uwagę, że propozycja Kaveney pokrywa się z przemyśleniami Umberta Eco, który opisuje popkulturowych supermanów (nadludzi) jako postaci cechujące się charyzmą, intelektem, tężyzną fizyczną i inicjatywą (przywracanie ładu w społeczeństwie zagrożonym przez jakieś zło) ${ }^{46}$.

Zgodnie z powyższymi propozycjami, superbohaterem może być postać o mitologicznym rodowodzie, protagonista, który został wprowadzony na karty komiksów w celach propagandowych, a swe nadludzkie zdolności posiadł na skutek modyfikacji genetycznych, np. Kapitan Ameryka, czy w końcu bohater bez jakichkolwiek mocy, by wskazać Iron Mana, Batmana i Czarną Wdowę. Geneza superbohatera nie jest cechą pierwszorzędną. Warunkiem koniecznym jest natomiast opowiadanie się za aksjosferą definiowaną jako dobro. Sherlock Holmes spełnia wszystkie powyższe wymagania. Trocha, powołując się na Mirceę Eliadego stwierdza, że protagonista opowiadań Artura Conana Doyle'a jest herosem walczącym ze złem, przywracającym prawo i porządek we wspólnocie, w której żyje ${ }^{47}$. Według znawcy literatury kryminalnej, Mariusza Czubaja, brytyjski pisarz stworzył pierwszego $\mathrm{w}$ historii literatury detektywa superbohatera. Podobną opinię sformułował Stephen Knight, uznając opowiadania z Sherlockiem Holmesem za apoteozę postaci detektywa, ponieważ przypisuje się mu w nich niemal boski status ${ }^{48}$.

\footnotetext{
44 B. W. Wright, Comic Book Nation, s. 19-21.

45 R. Kaveney, Superheroes! Capes and Crusaders in Comics and Films, London, New York 2008,
} s. 4 .

46 U. Eco, Superman w literaturze masowej. Powieść popularna: między retoryka a ideologia, przeł. J. Ugniewska, Kraków 2008.

47 B. Trocha, Typologia herosa w literaturze popularnej, s. 281.

48 Za: A. Depta, Początki kryminału - Auguste Dupin i Sherlock Holmes. Reminiscencje, w: Literatura popularna. Tom 3. Kryminat, red. E. Bartos, K. Niesporek, Katowice 2019, s. 147. 
Amerykański badacz i autor komiksów, Chris Gavaler, powołując się na Petera Coogana, proponuje bardziej precyzyjną definicję superbohatera:

Bohater heroiczny, bezinteresowny i działający dla dobra społeczeństwa. Obdarzony supermocami, do których można zaliczyć: nadzwyczajne zdolności, zaawansowane technologie, fizyczne, psychiczne i mistyczne umiejętności. Zrodzony w wyniku transformacji zwykłej postaci w superherosa. Pseudonim oraz symboliczny kostium są odzwierciedleniem jego życiorysu, charakteru oraz mocy. Często posiada dwie tożsamości, z których ta prawdziwa jest zazwyczaj pilnie strzeżona. Superherosa można odróżnić od postaci z publikacji typu fantasy, science fiction, powieści detektywistycznych itp., dzięki przewadze konwencji gatunkowych ${ }^{49}$.

Wymienione przez badacza kryteria właściwie wykluczają słynnego detektywa $\mathrm{z}$ grona superbohaterów. Jednak $\mathrm{w}$ dalszym toku swoich rozważań Gavaler podaje przykłady klasycznych oraz współczesnych komiksowych superherosów, którzy jedynie częściowo mieszczą się w formule zaproponowanej przez Coogana. I tak, członkowie Fantastycznej Czwórki używali pseudonimów, lecz nie ukrywali swej tożsamości i przez krótki czas nie nosili kostiumów ${ }^{50}$. Jessica Jones posiadała jedynie supermoce, była też prywatnym detektywem, co jednocześnie wykluczało bezinteresowność jej działań, a Batman nie dysponował ponadludzkimi atrybutami ${ }^{51}$. Nie można zatem mówić o istnieniu jednej, kompletnej i niepodważalnej definicji superbohatera, a stworzenie takiej może nastręczać trudności ze względu na różnorodność postaci pojawiających się na kartach komiksów.

Cytowany powyżej Gavaler, powołując się na Simona J. Evnine'a, rozpatruje gatunek w kategorii szczegółowych ",kontekstów historycznych", stwierdzając, że jeśli dzieło ma przynależeć do jakiegoś gatunku, musi być czytane i interpretowane $\mathrm{w}$ świetle wcześniejszych utworów oraz rozpatrywane w kategoriach „,rodowodu” i „wpływu” ${ }^{52}$. Ponadto uważa, iż komiks superbohaterski to zmieniający się zbiór cech formalnych, dlatego trudno w rozwa-

49 Tłumaczenie własne, w oryginale: „A heroic character with a selfless, pro-social mission; with superpowers - extraordinary abilities, advanced technology, or highly developed physical, mental, or mystical skills; who has a superhero identity embodied in a codename and iconic costume, which typically express his biography, character, powers, or origin (transformation from ordinary person to superhero); and who is generically distinct, i.e. can be distinguished from characters of related genres (fantasy, science fiction, detective, etc.) by a preponderance of generic conventions. Often superheroes have dual identities, the ordinary one of which is usually a closely guarded secret" [C. Gavaler, Superhero Comics, London, New York 2018, s. 1].

50 Tamże, s. 1-2.

51 Tamże, s. 2.

52 Tamże. 
żaniach nad nim pominąć prekomiksowe postaci, takie jak Zorro czy Hrabia Monte Christo ${ }^{53}$. Z tego też względu w przypadku opowieści o potężnych herosach nie możemy mówić o odrębności gatunkowej. Pierwszy komiks o Batmanie, opublikowany w 1939 roku na łamach dwudziestego siódmego numeru magazynu „Detective Comics”, był kryminałem, w którym komisarz Gordon i jego młody przyjaciel Bruce Wayne wyruszają na miejsce zbrodni, aby zbadać sprawę zabójstwa magnata przemysłu chemicznego, Lamberta ${ }^{54}$. Po zebraniu odpowiednich informacji Bruce, w tajemnicy przed kolegą, wymierza sprawiedliwość jako Batman. Ten schemat akcji Bob Kane i Bill Finger powielali w kolejnych historiach z Człowiekiem Nietoperzem. Opowieści z udziałem Fantastycznej Czwórki już od pierwszego zeszytu były utrzymywane $\mathrm{w}$ konwencji science fiction i grozy - uzyskanie supermocy podczas nieudanej misji kosmicznej oraz walka $\mathrm{z}$ istotami zamieszkującymi podziemia Nowego Jorku ${ }^{55}$, a debiut Doktora Strange'a miał charakter fantastyczny - tytułowy bohater włada magią, potrafi opuszczać swoje ciało i poruszać się w formie duchowej, a w celu uratowania mężczyzny, który prosi go o pomoc, przedostaje się do jego koszmarów ${ }^{56}$.

Z powodu popularności utworów Conan Doyle'a nie dziwi fakt, że Gōshō Aoyama wykorzystał postać Sherlocka Holmesa jako wzór dla Shin'ichiego/Conana. Uwagę zwraca już okładka pierwszego tomu mangi. Przedstawia ona tytułowego bohatera, który ma na sobie brązową myśliwską czapkę, dopasowane kolorystycznie ubranie (w tym płaszcz) oraz białe rękawiczki. Conan w jednej ręce trzyma fajkę. Taki strój natychmiast przywodzi na myśl Sherlocka Holmesa. Podobieństwo to autor mangi podkreślił, umieszczając w tle fotografię Londynu. Okładka pierwszego tomu stanowi przykład multimodalnego amalgamatu, która podobnie jak plakat jest skondensowaną formą mającą przekazać maksimum informacji w sposób szybki, prosty i atrakcyjny. Przez sięgnięcie po kompozycję pojęć z różnych przestrzeni wyjściowych tworzy ona nową, przykuwającą uwagę i nośną informacyjnie całość ${ }^{57}$.

\footnotetext{
53 Tamże.
}

54 Opis fabuły na podstawie przedruku z 1990 roku. DC Comics, Batman Archives. Volume I, New York 1990, s. 7-13.

55 S. Lee i in., Początki Marvela. Lata sześćdziesiąte, przeł. S. Smolarek, Warszawa 2015, s. 5-30.

56 S. Lee, S. Ditko, T. Szenics, Doktor Strange, mistrz czarnej magii!, w: Doktor Strange, przeł. J. Jankowski, Warszawa 2017, s. 7-11.

57 O plakatach kampanii społecznych jako multimodalnych amalgamatach pisała Justyna Winiarska. Zob. J. Winiarska, Plakat jako przyktad multimodalnego amalgamatu, "LingVaria" 2016, nr 2, s. 43-55. 


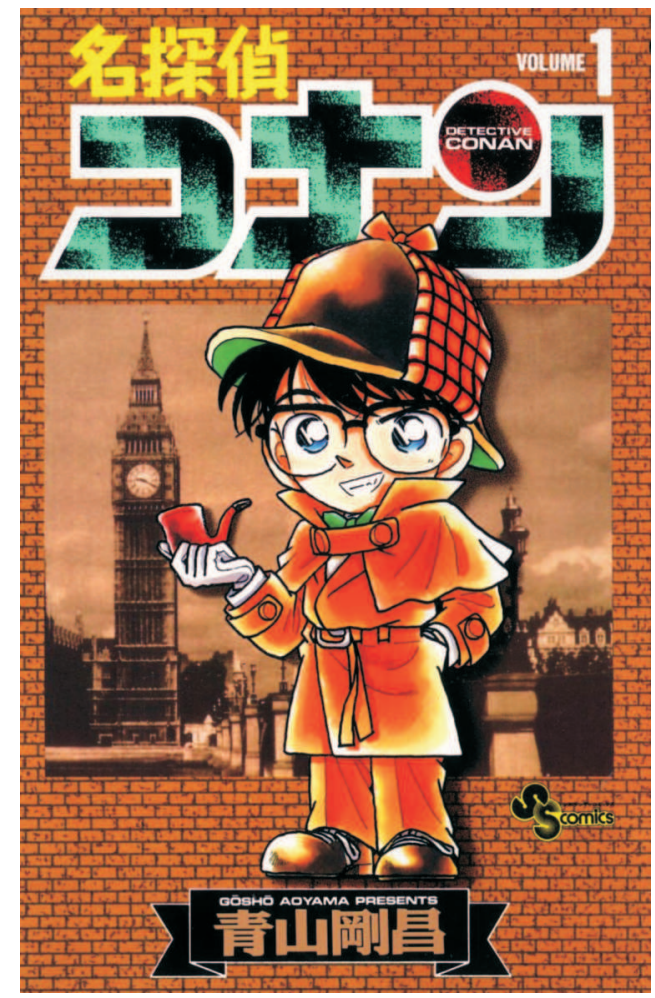

Okładka pierwszego tomu mangi Meitantei Conan. Gōshō Aoyama, Tokio 1994.

Tytuł pierwszego z rozdziałów mangi, Holmes ery Heisei ${ }^{58}$, będący jednym z przezwisk Shin'ichiego, również stanowi odniesienie do twórczości Artura Conana Doyle'a. Wraz z rozwojem akcji pojawiają się liczne sygnały intertekstualności. Główny bohater często komplementuje szkockiego pisarza jako twórcę najlepszego detektywa na świecie ${ }^{59}$. Shin'ichi chwali się, iż trenował piłkę nożną $\mathrm{w}$ celu wypracowania refleksu, dodając jednocześnie, że Sherlock Holmes uprawiał szermierkę ${ }^{60}$. Ponadto, aby jeszcze bardziej upodobnić się do swojego ulubieńca, nastolatek opanował grę na skrzypcach ${ }^{61}$. Shin'ichi posiada doskonały zmysł obserwacji, a w trakcie pracy wykorzystuje wiedzę z różnych dziedzin nauki. Przykładem może być sprawa

\footnotetext{
58 Tłumaczenie własne, w oryginale: 平成のホームズ (Heisei no Holmes). G. Aoyama, Meitantei Conan, t. 1, s. 5 .

59 Tamże, s. 13.

60 Tamże.

61 W dwunastym filmie kinowym Shin'ichi wykonuje dla Ran utwór Amazing Grace. Meitantei Conan: Senritsu no Full Score, reż. Y. Yamamoto, Japonia 2008.
} 
zabójstwa w parku rozrywki dokonanego podczas przejażdżki kolejką górską. Choć początkowo tajemnica zbrodni wydawała się nierozwiązywalna, detektyw-amator udowodnił, że dzięki odpowiedniemu zblokowaniu mechanizmów zabezpieczających pasażera przed wypadnięciem, jak również wykorzystaniu prędkości, z jaką poruszały się wagoniki, oraz cienkiej żyłki przestępca pozbawił swoją ofiarę głowy ${ }^{62}$.

Shin'ichi jawi się więc jako genialny nastolatek, który stoi na straży prawa i porządku, wpisując się tym samym w zaproponowaną przez Kaveney definicję superbohatera. Taka kreacja postaci ma niewątpliwie wydźwięk humorystyczny, wszak zaledwie siedemnastoletni Kudō uważany jest za wybawcę policji, która bez jego wsparcia nie poradziłaby sobie z rozwiązywaniem spraw kryminalnych. Komiksowy detektyw-amator spełnia też kilka kryteriów wymienionych przez Coogana: przechodzi transformację i przyjmuje tajną tożsamość ucznia pierwszej klasy szkoły podstawowej, prowadząc podwójne życie.

Przemiana Shin'ichiego w Conana na skutek próby otrucia go przez członków Czarnej Organizacji inspirowana jest opowieściami o genezach amerykańskich superbohaterów (tzw. Origin story), mającymi na celu wyjaśnienie, w jaki sposób doszło do "narodzin” danego herosa. Nierzadko są to fabuły, u podstaw których leży osobista tragedia przyszłego wybawcy ludzkości. Przykładowo Fantastyczna Czwórka została zbombardowana przez deszcz meteorytów podczas podróży kosmicznej, Bruce Banner zyskał możliwość przemiany w Hulka na skutek wybuchu ładunku gamma, a Tony Stark stworzył zbroję Iron Mana, aby uwolnić się z niewoli i zatrzymać odłamek metalu tkwiący $\mathrm{w}$ jego ciele przed dostaniem się do serca ${ }^{63}$. Herosa wykreowanego przez Aoyamę wyróżnia jednak jeden istotny szczegół, protagonista omawianej franczyzy przechodzi transformację w osobę przypominającą swym wyglądem dziecko (Conan udaje ucznia szkoły podstawowej). Amerykańscy superbohaterowie pokroju Batmana, Supermana czy Wonder Woman są dorośli lub mają po kilkanaście lat, np. Spider-Man debiutuje jako licealista ${ }^{64}$, jednak wraz $\mathrm{z}$ rozwojem fabuły uczęszcza już na studia. W innych przypadkach są dziećmi, jak choćby wzmiankowany wcześniej Billy Batson/Kapitan Marvel. Należy jednak zwrócić uwagę, że po przemianie $w$ herosa Billy wygląda jak dorosły mężczyzna ${ }^{65}$. Taka kreacja

\footnotetext{
62 Tamże, s. 16-33.

63 S. Lee i in., Początki Marvela. Lata sześćdziesiąe, s. 15-18, 43-45, 80-84.

64 Tamże, s. 65.

65 Por. J. Smith, S. Hamaker, Shazam! Potworne stowarzyszenie zła, przeł. T. Sidorkiewicz, Warszawa 2019.
} 
Conana wynika z faktu, iż Meitantei Conan jest mangą shōnen. Publikacje tego typu skierowane są do dorastających chłopców i mają na celu ukazanie swoim odbiorcom wartości przyjaźni oraz wytrwałości ${ }^{66}$. Ponadto protagoniści mang shōnen przechodzą różnorodne próby i doznają życiowych niepowodzeń. Związane jest to $\mathrm{z}$ faktem, że ten typ japońskich komiksów ma wprowadzić swoich odbiorców w dorosłość. Tymczasem amerykańskie fabuły superbohaterskie zwyczajowo nie są dzielone ze względu na wiek i płeć czytelników (z wyjątkiem wydawnictw od samego początku tworzonych $\mathrm{z}$ myślą o pełnoletnich osobach). $\mathrm{Z}$ tego względu herosi ze Stanów Zjednoczonych Ameryki niemal w ogóle się nie starzeją, a publikacje z ich przygodami czytają wszyscy. Ponadto Conan stara się odzyskać dawne ciało, czyli niejako zrezygnować ze swojej superbohaterskości i wrócić do dawnego status quo, co również wyróżnia go na tle kolegów z Zachodu, wiecznie trwających w swym "zawodzie".

To jeszcze nie wszystkie elementy kreacji postaci protagonisty cyklu Gōshō Aoyamy przemawiające za jego statusem superbohatera. Chłopiec $\mathrm{w}$ trakcie prowadzenia śledztw posługuje się zdolnościami, które zdobył jako Shin'ichi (np. potrafi celnie kopać i posługiwać się bronią palną). Dzięki zyskaniu zaufania przedstawicieli tokijskiej policji, niczym Bruce Wayne, towarzyszy funkcjonariuszom $\mathrm{w}$ trakcie śledztw i wykorzystuje zebrane $\mathrm{w}$ ten sposób informacje do rozwiązania zagadki tożsamości przestępcy. Conan często przebywa w towarzystwie ojca Ran, który jest prywatnym detektywem, co dodatkowo umożliwia mu przeszukiwanie miejsc zbrodni. Należy jednak zwrócić uwagę na fakt, że Kogorō zyskał sławę i rozgłos za sprawą działalności Edogawy. Aoyama wykreował postać Conana posługując się zabiegami zbliżonymi do parodii ${ }^{67}$ - w komiczny sposób naśladuje wygląd klasycznego literackiego detektywa (połączenie eleganckich elementów ubioru takich jak muszka i marynarka z krótkimi spodniami oraz trampkami), jego nawyki (gromadzenie świadków zbrodni w jednym pokoju, celem wyjawienia tożsamości przestępcy), gesty i atrybuty. Uczeń pierwszej klasy szkoły podstawowej pomagający policji w rozwiązywaniu spraw powinien wzbudzać wiele podejrzeń, tymczasem wszyscy przechodzą nad tym do porządku dziennego. Niekiedy zdarza się, że Conan ma styczność z policjantami z innych rejonów Japonii, którzy początkowo nastawieni są do niego sceptycznie, jednak w trakcie kolejnych spotkań korzystają z jego pomocy. W filmie Meitantei Conan: Shikkoku no Chaser funkcjonariusze policji pytają Kogorō czy

66 J. E. Ingulsrud, K. Allen, Reading Japan Cool, s. 10.

67 W rozumieniu Ryszarda Nycza. Zob. Tegoż, Tekstowy świat. Poststrukturalizm a wiedza o literaturze, Kraków 2000, s. 200-201. 

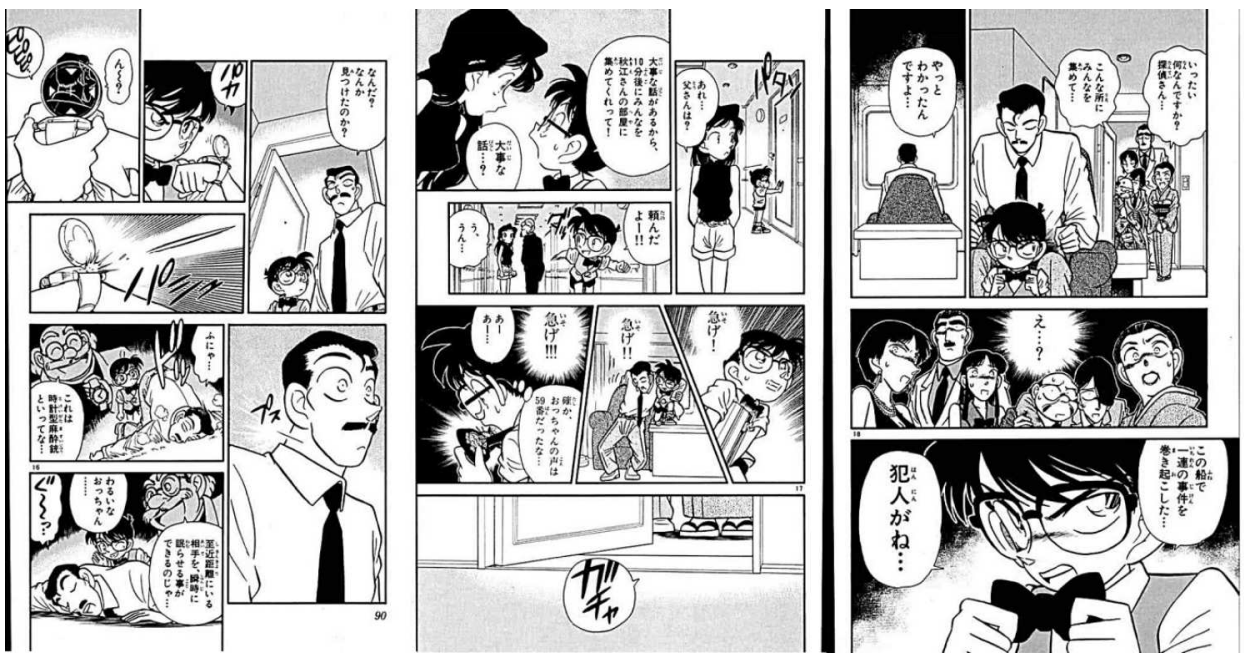

Conan Edogawa podszywający się pod detektywa Kogorō Mōriego, w celu wyjawienia tożsamości przestępcy. G. Aoyama, Meitantei Conan t. 3, Tokio 1994, s. 90-92.

nie przyprowadził ze sobą Conana, ponieważ w jego obecności sprawy zawsze się rozwiązują ${ }^{68}$. Świadczy to o "omnipotencji" i wszechwiedzy protagonisty cyklu Aoyamy.

Edogawa, podobnie jak Batman, Spider-Man, Iron Man czy James Bond $^{69}$, posiada specjalne gadżety, które pomagają mu w pracy. Każdy z nich został stworzony przez profesora Agasę. Wśród najważniejszych należy wymienić: muszkę pozwalającą na zmianę głosu oraz zegarek z usypiającymi wystrzeliwanymi igłami (Conan wykorzystuje je, aby podszyć się pod osobę, która jego zdaniem powinna rozwiązać konkretne śledztwo, i nie wzbudzać podejrzeń co do jego udziału w sprawie) ${ }^{70}$, okulary z kuloodpornymi szkłami, funkcją przybliżania widoczności i namierzania pluskiew, trampki zwiększające siłę kopnięcia, napędzaną światłem słonecznym deskorolkę oraz pasek z wystrzeliwanymi, samopompującymi się piłkami nożnymi. Jed-

68 Meitantei Conan: Shikkoku no Chaser, reż Y. Yamamoto, Japonia 2009.

69 Zestawienie Jamesa Bonda $\mathrm{z}$ komiksowymi superbohaterami może wydawać się dyskusyjne. Ale warto zauważyć, że U. Eco wyraźnie określa bohatera powieści Iana Fleminga mianem supermana (nadczłowieka) pojawiającego się w spy thriller. Ponadto Gōshō Aoyama poświęcił dwudziestą siódmą odsłonę swojej Ilustrowanej encyklopedii detektywów Jamesowi Bondowi, co można odczytać jako wyraźny sygnał, iż Conan Edogawa był w pewnym stopniu wzorowany również na nim. Zob. U. Eco, Superman w literaturze masowej, s. 7; G. Aoyama, Meitantei Conan, t. 27, Tokio 2000, obwoluta.

70 Conan po rozwiązaniu zagadki tożsamości przestępcy usypia Kogorō lub inną postać za pomocą igły, po czym pomaga jej usiąść na krześle lub fotelu, następnie chłopak chowa się za swoją "ofiarą" i używa muszki zmieniającej głos, aby wyjawić prawdę na temat mordercy. 
nak najistotniejszymi cechami świadczącymi o heroiczności Conana są solidarność z pokrzywdzonymi oraz chęć niesienia pomocy ofiarom zbrodni. Protagonista mangi Aoyamy reaguje na każdy krzyk i niecodzienny hałas, które z pewnością zostałyby zignorowane przez innych obywateli. Detektyw-amator przywraca ład i porządek na terenie Tokio oraz innych miast, które odwiedza w trakcie podróży ${ }^{71}$.

Manga Meitantei Conan autorstwa Gōshō Aoyamy i jej adaptacje stanowią przykład dzieł wpisujących się w nurt synkretyzmu kulturowego, cechującego się złożonością, przenikaniem wzorców czy licznymi zapożyczeniami, które prowadzą do uniwersalizacji przekazu oraz stworzenia produktu atrakcyjnego dla odbiorców na całym świecie ${ }^{72}$. Japoński artysta posłużył się atrakcyjną z punktu widzenia młodego odbiorcy figurą nastoletniego detektywa herosa, który rzuca wyzwanie przestępczości, a w swych działaniach okazuje się być bardziej skuteczny niż dorośli. Połączenie elementów kryminalnych z superbohaterskimi, oraz częściowe ich sparodiowanie i zdeprecjonowanie transformacja genialnego siedemnastolatka w młodsze o dziesięć lat dziecko, któremu niestraszne są przestępstwa, świadczy o tym, że Gōshō Aoyamie, posługującemu się elementami typowymi dla poetyki postmodernistycznej, zależy na podjęciu gry z odbiorcą, wytrąceniu go ze schematycznego myślenia o superbohaterach i powieści detektywistycznej. Conan Edogawa z pewnością jest nietypowym superherosem, który podobnie jak Superman, Wonder Woman czy Batman ma zachwycać odbiorców swymi niecodziennymi przygodami, kusić obietnicą przezwyciężenia każdego zła oraz przywrócenia ładu i porządku.

\section{Bibliografia}

Aoyama Gōshō (2011), Magic Kaito Treasured Edition t. 1, Tokio: Kabushiki gaisha Shōgakukan.

Aoyama Gōshō (1994), Meitantei Conan, t. 1-3, Tokio: Kabushiki gaisha Shōgakukan. Aoyama Gōshō (1995), Meitantei Conan, t. 4, Tokio: Kabushiki gaisha Shōgakukan. Aoyama Gōshō (1997), Meitantei Conan, t. 16, Tokio: Kabushiki gaisha Shōgakukan.

71 Walka dobra ze złem, w tym przypadku Conana Edogawy z przestępcami, rozstrzygająca się w każdym przypadku na korzyść dobra (pomimo rozwiązań przynoszących mieszaninę radości i nieszczęścia), jest elementem charakterystycznym dla powieści popularnej. Zob. U. Eco, Superman $w$ literaturze masowej, s. 18-20.

72 T. Bazylewicz, P. Jankowski, Synkretyzm kulturowy na wybranych przyktadach. Analiza krytyczna Ghost in the Shell, Appleseed oraz Fullmetal Alchemist, "Zeszyty Komiksowe” 2012, nr 13, s. 81 . 
Aoyama Gōshō (1998), Meitantei Conan, t. 19, Tokio: Kabushiki gaisha Shōgakukan. Aoyama Gōshō (1998), Meitantei Conan, t. 21, Tokio: Kabushiki gaisha Shōgakukan. Aoyama Gōshō (2000), Meitantei Conan, t. 27, Tokio: Kabushiki gaisha Shōgakukan. Aoyama Gōshō (2005), Meitantei Conan, t. 48-49, Tokio: Kabushiki gaisha Shōgakukan. Aoyama Gōshō (2008), Meitantei Conan, t. 61, Tokio: Kabushiki gaisha Shōgakukan. Aoyama Gōshō (2014), Meitantei Conan, t. 84, Tokio: Kabushiki gaisha Shōgakukan. Aoyama Gōshō (2019), Meitantei Conan, t. 96, Tokio: Kabushiki gaisha Shōgakukan. Bazylewicz Tomasz, Jankowski Przemysław (2012), Synkretyzm kulturowy na wybranych przyktadach. Analiza krytyczna Ghost in the Shell, Appleseed oraz Fullmetal Alchemist, „Zeszyty Komiksowe”, nr 13, s. 81-85.

Chudi X, Lupin, Blade i Detektyw Conan na antenie AXN Spin, https://anime.com.pl/ Lupin\%2C_Blade_i_Detektyw_Conan_na_antenie_AXN_Spin,news,read,6303.html [dostęp 08.03.2020].

Czubaj Mariusz (2010), Etnolog w Mieście Grzechu. Powieść kryminalna jako świadectwo antropologiczne, Gdańsk: Oficynka.

DC Comics (1990), Batman Archives. Volume I, New York: DC Comics INC.

Depta Anna (2019), Początki kryminału - Auguste Dupin i Sherlock Holmes. Reminiscencje, w: Literatura popularna. Tom 3. Kryminał, red. E. Bartos, K. Niesporek, Katowice: Wydawnictwo Uniwersytetu Śląskiego, s. 141-154.

Detective Conan w bazie MyAnimeList, https://myanimelist.net/manga/11176/ Detective_Conan [dostęp 08.09.2020].

Dmitruk Natalia (2017), Wierzenia z perspektywy japońskiej. Mushishi Yuki Urushibary, „Literatura i Kultura Popularna”, nr 23, s. 93-107.

Eco Umberto (2008), Superman w literaturze masowej. Powieść popularna: między retoryka a ideologia, przeł. Joanna Ugniewska, Kraków: Wydawnictwo Znak.

Gavaler Chris (2018), Superhero Comics, London, New York: Bloomsbury.

Gosho Aoyama's Profile, oficjalna strona internetowa Gōshō Aoyama Manga Factory, https://www.gamf.jp/english/41.html [dostęp 23.02.2020].

Hajdu David (2008), The Ten-Cent Plague. The Great Comic-Book Scare and How It Changed America, New York: Farr, Straus and Giroux.

Ingulsrud John E., Allen Kate (2009), Reading Japan Cool. Patterns of Manga Literacy and Discourse, Lanham: Lexington Books.

Jenkins Henry (2007), Kultura konwergencji. Zderzenie starych i nowych mediów, przeł. M. Bernatowicz, M. Filiciak, Warszawa: Wydawnictwo Akademickie i Profesjonalne.

Kaveney Roz (2008), Superheroes! Capes and Crusaders in Comics and Films, London, New York: I.B. Tauris.

Kołsut Rafał (2019), Pradziadkowie Supermana - genealogia komiksowych superbohaterów, w: Heroica. Bohaterstwo w literaturze i kulturze europejskiej, red. A. Gawarecka, W. Szturc, E. Wesołowska, Poznań: Wydawnictwo Naukowe Uniwersytetu im. Adama Mickiewicza, s. 297-314.

Lee Stan i in. (2015), Początki Marvela. Lata sześćdziesiąte, przeł. S. Smolarek, Warszawa: Hachette Polska. 
Lee Stan, Ditko Steve, Szenics Terry (2017), Doktor Strange, mistrz czarnej magii!, w: Doktor Strange, przeł. J. Jankowski, Warszawa: Hachette Polska, s. 7-11.

Meitantei Conan: Zero no Tea Time w bazie MyAnimeList, https://myanimelist.net/ manga/114379/Meitantei_Conan_ZZero_no_Tea_Time [dostęp 08.09.2020].

Marciniak Paweł (2015), Transfikcjonalność, „Forum Poetyki”, nr 2, s. 102-106.

Materne Agnieszka (2019), Fenonem mangi $i$ anime w środowisku młodziė̇y. Studium dyfuzji kultur, Kraków: Impuls.

Nycz Ryszard (2000), Tekstowy świat. Poststrukturalizm a wiedza o literaturze, Kraków: Universitas.

Oficjalna strona serialu aktorskiego Kudō Shin'ichi e no Chōsenjō, https://www.ytv.co. jp/conan-drama/ [dostęp 08.09.2020].

Olkusz Ksenia (2018), Transfikcjonalność w literaturze, „Zagadnienia Rodzajów Literackich", nr 61, z. 1, s. 159-165.

Opis 12. odcinka serii Detektyw Conan, http://www.tv.pl/opis/s_6_p_9452_Detektyw_ Conan.xhtml [dostęp 08.03.2020].

Rembowska-Płuciennik Magdalena (2012), Poetyka intersubiektywności. Kognitywistyczna teoria narracji a proza XX wieku, Torun: Wydawnictwo Naukowe Uniwersytetu Mikołaja Kopernika.

Smith Jeff, Hamaker Steve (2019), Shazam! Potworne stowarzyszenie zła, przeł. T. Sidorkiewicz, Warszawa: Egmont Polska.

Trocha Bogdan (2019), Typologia herosa w literaturze popularnej, w: Heroica. Bohaterstwo w literaturze i kulturze europejskiej, red. A. Gawarecka, W. Szturc, E. Wesołowska, Poznań: Wydawnictwo Naukowe Uniwersytetu im. Adama Mickiewicza, s. 279-296.

TMS Entertainment USA, A Massive Hit Series! Detective Conan: The Fist of Blue Sapphire, to be Released Nationwide in Japan on April 12th, 2019, http://www.tms-e. co.jp/english/pdf/20190408_conan_movie_en.pdf [dostęp 23.02.2020].

Więckowski Jacek (2012), Detective Conan - na tropie swojego ciała. Świat pod lupa, „Magazyn Arigato. Azjatycki Komiks i Animacja”, nr 14, s. 38-39.

Winiarska Justyna (2016), Plakat jako przykład multimodalnego amalgamatu, „LingVaria”, nr 2, s. 43-55.

Wright Bradford W. (2003), Comic Book Nation. The Transformation of Youth Culture in America, Baltimore \& London: The Johns Hopkins University Press.

Yaiba w bazie MyAnimeList, https://myanimelist.net/manga/1631/Yaiba [dostęp 23.02.2020].

Zaremba-Penk Joanna (2019), Ikonografia mangi. Wpływy tradycji rodzimej i zachodnich twórców na wybranych japonskich artystów mangowych, Bydgoszcz: Wydawnictwo Kirin.

Zawrotny Przemysław (2018), Zamiana herosa w superherosa, "Zeszyty Komiksowe", nr 26, s. 4-12.

Żaglewski Tomasz (2017), Kinowe uniwersum superbohaterów. Analiza wspótczesnego filmu komiksowego, Warszawa: Wydawnictwo Naukowe PWN. 


\title{
Filmografia
}

Detektyw Conan: Architekt zniszczenia, reż. Kenji Kodama, Japonia 1997.

Detektyw Conan odc. 1; 146-147; 162; 425, reż. Kenji Kodama i in., Japonia 1996; 1999; 2006.

Meitantei Conan Magic File 2: Kudou Shin'ichi Nazo no Kabe to Kuro Lab Jiken, reż. Yasuichiro Yamamoto, Japonia 2008.

Meitantei Conan: Baker Street no Bōrei, reż. Kenji Kodama, Japonia 2002.

Meitantei Conan: Seikimatsu no Majutsushi, reż. Kenji Kodama, Japonia 1999.

Meitantei Conan: Shikkoku no Chaser, reż. Yasuichiro Yamamoto, Japonia 2009.

Meitantei Conan: Senritsu no Full Score, reż. Yasuichiro Yamamoto, Japonia 2008.

\section{Conan Edogawa - Detective from Comics by Gōshō Aoyamy as a Superhero}

\begin{abstract}
The aim of this paper is a character analysis of Conan Edogawa the protagonist of Meitantei Conan by Gōshō Aoyama - as a variation of the superhero. The research material includes manga, animated series adaptation and related cinematic films. The broadly understood criminal novel (mostly the Sherlock Holmes cycle by Arthur Conan Doyle) was the source of inspiration for the Japanese artist. The analysis of the collected material demonstrates that the described franchise used a transmedia narration. Both Aoyama and the authors of animated adaptations use transfictionality in their works. With the combined usage of the criminal and superhero elements, the Japanese artist created an omnipotent and omniscient superhero detective who can solve any mystery.
\end{abstract}

Keywords: comics, detective fiction, superhero, manga, Conan Edogawa, Sherlock Holmes 